\title{
STABILIZATION PLANNING UNDER THE NATIONAL SECURITY ACT*
}

\author{
James A. Durham $\dagger$ and Benjamin Capian $\ddagger$
}

It is a melancholy reflection that the past fifteen years have seen the rise of a new activity, if not a new profession, dealing with problems and strategy of war mobilization. Twice within that period it has been necessary to deal with such problems on an operating basis. Currently, the problems are still being dealt with, fortunately thus far only on a planning and programming, but, none the less, real and challenging basis.

\section{The Changing Mobilization Problem}

What constitutes the nature of the challenge is the changing character of the mobilization problem. In World War II, it was the problem of what is now labeled, perhaps wistfully, "conventional full mobilization." During the Korean experience, it was a case of "partial mobilization." Tomorrow's challenge and grim threat stem trom the opening of the Pandora's box of nuclear energy. Whether, in fact, the grim threat of atomic destruction actually will ever have to be faced, no one can say. Indeed, it may well be that its great capacity for destructiveness is the world's best safeguard and that the problems of mobilization in the future will be more or less of the same kind as we have already experienced. But it would be reckless to count on that relatively optimistic outlook and hence we must prepare for the possibility of massive destruction.

These general remarks have an important bearing on the development of stabilization programming which is the principal concern of this symposium. For, clearly, stabilization as well as production controls, materials distribution, manpower allocations, and others are merely facets of the broad plan of mobilization strategy. This must be true in principle, however difficult it may be to achieve in practice. The problem is to determine within the broad contest of alternative mobilization contingencies, the alternative and appropriate types of stabilization policies and actions.

There is, however, a difficulty which seems peculiar to stabilization planning and operations. It has always enjoyed the dubious distinction of being the most controversial aspect of mobilization. Yet, wartime inflation has been rightly recognized as a destroyer of economic balance and a creator of social conflict and as such,

"The opinions expressed herein are those of the authors and do not necessarily represent those of any past or present Government agency.

tStabilization Counsel, Office of Defense Mobilization; formerly Acting Gencral Counsel, Economic Stabilization Agency; Associate Chief Counsel, Office of Price Stabilization; and Attorney, Office of Price Administration.

‡Economist, Schenley Industries, Inc.; formerly Stabilization and Production Economist, Office of Defense Mobilization; Chief Economist, Economic Stabilization Agency; and Economist, Council of Economic Advisers and Office of Price Administration. 
equally unpopular. The existence of this paradox, for such it is, raises the question of why this should be so.

There are a number of factors which will help to furnish at least a partial explanation. In the first place, stabilization controls have the widest direct impact on the community: they affect directly buyers and sellers, consumers and workers, borrowers and lenders, and taxpayers. All of us are in one or more of these categories. Second, the imposition of price and wage controls deprives the economy of its usual freedom to adjust prices and wages and substitutes a great deal of onerous paperwork to show compliance. Third, the function of stabilization is both to facilitate the orderly shift of resources to military use and to preserve the balance between the various groups in the economy-labor, management, farmers, and consumers. This dual objective can and does lead to conflict since producer interests can stress the importance of production objectives and the need for price and wage increases while the balancing of interest approach leads to emphasis on avoiding such increases. Thus, what are normally the functions of the market become transformed into basic political issues. The reconciliation of these two objectives then becomes a highly complicated and controversial activity.

All sides are agreed in principle on the great undesirability of permitting wartime inflation to rage unchecked. The issue, as always, is over ways and means. How far can we rely on the so-called indirect methods of stabilization-e.g., fiscal and credit measures? To what exent do we have to supplement them immediately or ultimately by direct controls over prices and wages? The very rapid rise of prices and wages in the second half of $195^{\circ}$ showed how quickly inflation can take wing. Does that experience mean that government should be prepared to impose such controls as soon as an emergency develops? Should government have the power in being now, or can it wait until the emergency actually develops before asking for the authority?

These are some of the issues which will be discussed in this paper. This will involve a description of the government's planning program, its emphases, and problems; the legislative background of the program; and some comment on the problem of making a planning effort operationally useful.

\section{Planning Without Operating Authority}

The statutory authority for the formulation of stabilization measures by the Office of Defense Mobilization is Section ro3 of the National Security Act of $1947,{ }^{1}$ which provides that the National Security Resources Board will advise the President on "programs ... for the maintenance and stabilization of the civilian economy in time of war, and for the adjustment of such economy to war needs and conditions ...." By Reorganization Plan No. 3 of $1953,{ }^{2}$ among other things abolishing the National Security Resources Board, this function was transferred to the Office of Defense Mobilization, where it now resides. In addition, by Section ror(a) of Executive

${ }^{1} 6 \mathrm{r}$ StaT. 499 (1947), as amended, 64 STAT. I280 (1950), 50 U. S. C. $\$ 404$ (c)(2) (Supp. 1952).

2 I8 FED. REG. 3375 (1953). 
Order 10480 of August I8, I953, the Director of the Office of Defense Mobilization was instructed to "coordinate all mobilization activities of the executive branch of the Government, including all such activities relating to ... stabilization...."

Such congressional authority is, while adequate to support a stabilization planning agency, of course, insufficient to launch an operating price stabilization program. It was this very question-i.e., whether planning could be effective in the absence of standby operating authority-which was the heart of the issue raised by the introduction of bills by Senator Capehart and others in the first session of the present Congress. The result of that experience was an express acceptance by the Administration of stabilization planning responsibility and an understanding by Congress that such responsibility would be carried out without the necessity of a standby law.

In January 1953, when the present Administration came into office, Title IV of the Defense Production Act of $1950^{4}$ still authorized the fixing of price and wage ceilings by governmental authority. But like all past stabilization legislation of this kind, Title IV had but a short time to run-specifically until April 30, I953. Without powerful presidential interference, such controls were expected to elapse. In his State of the Union Message of February 2, 1953, ${ }^{5}$ President Eisenhower announced that no renewal of legislative authority in this area would be requested, and that in fact he proposed to remove such controls promptly. Wage ceilings were immediately withdrawn, and an orderly program of price decontrol actions was begun.

\section{A. Comparison of Standby Bills}

On the same day as the State of the Union Message, Senator Capehart introduced the first of two bills which have been conveniently referred to as "standby" measures. The first of these ${ }^{b}$ contemplated that once these controls expired, the President could renew them, either generally or selectively, after prior consultation with a National Advisory Council and after an appropriate finding of necessity. This bill also continued the organizational framework for controls which had grown out of Title IV of the Defense Production Act. Specific planning functions were assigned in the absence of the reactivation of controls: ${ }^{62}$

Sec. 402. . . . to establish and maintain procedures for the study and evaluation of price and wage trends; to make monthly reports to the Congress with respect to these and related matters, and any special reports that bear upon the proper administration of this title; to formulate and recommend to the President general policies and regulations relating to controls on prices and on wages, salaries, and other compensation; to consult with advisory committees with respect to

\footnotetext{
${ }^{3}$ Id. at 4939 .

‘64 STAT. 798 (1950), as amended, 66 STAT. 296 (1952), 50 U. S. C. App. \$206r-2166 (Supp. 1952).

The State of the Union-Address by the President of the United States, H. REP. Doc. No. 75, 83d Cong., Ist Sess. (1953); 99 CoNG. Rec. 748-753 (1953).

'S. 753 (Emergency Stabilization Act of 1953), 83d Cong., Ist Sess. (1953). Senator Capehart's reasons for sponsoring this bill were explained at length in his article, Cutrent Developments in Price Control Legislation: A Safe Middle Way, 38 Iowa L. Rev. 222 (1953).

oa 99 CONG. REC. 717, at 721 (1953).
} 
price trends and the improvement of pricing techniques which may be employed in future regulations; to draft for possible future use new and simplified regulations incorporating improved techniques suggested by such committees and prior experience in the administration of controls; . . . to maintain current rosters of qualified persons who would be available in the event of the activation of controls... and to devise and perfect the appropriate pattern of organization and procedures which would be required in the event it should become necessary to impose selective or general controls.

In the event of such reactivation, the bill provided for a freeze of prices and wages at then current levels, plus subsequent reconsideration of the freeze levels by reference to particular standards. The bill omitted nearly all of the special interest amendments, including the Capehart Amendment of $195^{\mathrm{r}}$, which had been added to the Defense Production Act since $195^{\circ}$.

Shortly thereafter, on February I8, I953, Congressman Multer of New York offered a bill providing only for a presidential freeze of 90 days' duration, without any prior consultation. $^{7}$ The temporary character of this bill was emphasized by an express provision barring challenges to the validity of any regulation, since the price field historically has been an area for full judicial review. Subsequently the identical bill was reintroduced by sixteen additional Congressmen, ${ }^{8}$ as the Rules of the House do not provide for joint sponsorship.

Senator Capehart's second bill ${ }^{9}$ was offered on February 25, 1953, under the joint sponsorship of all but three of the members of the Senate Committee on Banking and Currency. This bill provided merely for a 90 day freeze order, but continued the requirement of prior consultation with a National Advisory Council. This time no provision was made for the continuation of any existing agencies. As in the Multer bill, the base period employed for any price freeze must be a period within one month prior to the issuance of the freeze order. Unlike the Multer bill, the second Capehart bill failed to contain a clause barring a challenge to the validity of the go day freeze order; nor did it contain provisions for administrative reconsideration and judicial review of the freeze and its amendments.

\section{B. Legislative Disposition of the Bills}

From March until June I953 hearings were held and these bills were debated. The only witness firmly endorsing the standby bills was Mr. Bernard Baruch, who preferred a one-year freeze bill to the 90 day freeze authorized by Senator Capehart's second bill. ${ }^{10}$ On behalf of the Administration, Mr. Arthur S. Flemming, Director of the Office of Defense Mobilization, opposed the enactment of a standby law, par-

${ }^{7}$ H. R. 3184,83 d Cong., Ist Sess. (1953).

${ }^{8}$ H. R. 34 I 4 , H. R. 3470 , H. R. 3475 , H. R. 3479 , H. R. 3484 , H. R. 3485 , H. R. 3486 , H. R. 3497 , H. R. 3532 , H. R. 3677 , H. R. 3578 , H. R. 3592 , H. R. 36 ro, H. R. 3633 , H. R. 3651 , and H. R. 3657all in Eighty-third Congress, First Session (1953).

${ }^{\circ}$ S. 1081, 83d Cong., rst Sess. (1953).

${ }^{10}$ Hearings before the Senate Committee on Banking and Currency on S. 753 and S. ro81, 83d Cong., Ist Sess. 714-760 (Part 2) (1953). Another forceful statement of this position appears in Ginsberg, Price Stabilization, 1950-1952: Retrospect and Prospect, 100 U. of PA. L. Rev. 514 (1952). 
ticularly if it took any detailed form. ${ }^{11}$ On the other hand, he stated that if Congress felt that it could not move rapidly enough to enact controls promptly in case of an emergency, then the general go-day freeze bill would be acceptable to the Administration. Tentatively at least, Mr. Flemming told the Committee that in the event of an emergency the Administration would request that Congress enact within Io days a 90 day freeze bill containing a pre-emergency base period. Whether or not Congress enacted the 90 day bill in the 1953 session, Mr. Flemming indicated that under any circumstances the Administration proposed to engage in planning for wartime stabilization under the authority of the National Security Act.

The Senate Committee recommended the passage of the go day freeze bill, with three members dissenting. ${ }^{12}$ The Committee argued that it was a forlorn hope to expect Congress to act quickly to pass a freeze measure in case of an emergency, referring to the time taken to pass the Emergency Price Control Act of 1942 and the Defense Production Act of $195^{\circ}$. In contrast, the dissenting members argued that Congress could enact such a measure within to days-_"when and if needed."13 The minority expressly indicated their desire that Congress, rather than the President, make the finding of whether an emergency existed and the character of the freeze controls: $:^{14}$

If Congress creates the freeze, then Congress will write the legislation to take effect at the end of the freeze period. If the President creates the freeze ... he can also set the pattern for the succeeding legislation, and Congress will have little opportunity to do more than ratify the Presidential edict.

The Senate passed the Committee-sponsored standby bill, but only after adopting an amendment by Senator Byrd prohibiting the President from using a freeze regulation except "whenever the United States has declared war against a foreign nation, or whenever Congress, by concurrent resolution," authorized use of this power. ${ }^{15}$ The shifting of authority led the Administration, through Mr. Flemming's testimony before the House Banking Committee, to oppose outright the Senate bill. ${ }^{10}$ The House Committee refused to accept the 90 day freeze bill, either as it came from the Senate Committee, or with the Byrd Amendment attached. ${ }^{17}$ The Committee asserted that Congress not only can but would act swiftly to legislate controls in the event of an emergency, ${ }^{18}$ and that the experiences of $194^{2}$ and $195^{\circ}$ were inapplicable since in those cases Congress drafted detailed rather than general freeze authority. ${ }^{19}$ A large minority of the Committee sought to strike the Byrd

${ }^{11}$ Hearings, supra, at 1275-1333 (Part 4).

${ }^{12}$ Sen. Rep. No. 138, Standey Economic Controls, Report from the Committee on Banking and Currency to Accompany S. I081, 83d Cong., ist Sess. (1953).

${ }^{13} \mathrm{Id}$. at 45 .

${ }^{15} 99$ Cong. Rec. 5084 (1953). The vote favoring the Byrd Amendment was 45-41, with Senator Capehart bearing the brunt of the debate against it.

${ }_{10}$ Hearings before the House Committee on Banking and Currency on S. 1081, 83d Cong., Ist Sess. $7-48$ (r953).

${ }^{17}$ H. REP. No. 516, 83d Cong., Ist Sess. (1953).

${ }^{18}$ Id. at II.

${ }^{10}$ Id. at 13 . 
Amendment from the bill, but, when this failed, voted against the freeze bill. ${ }^{20}$

Thus ended the legislative debate over whether effective stabilization planning required present authority to place the plans in action. But the result was in no sense a defeat for a planning program. Not only had the Administration announced the existence of such a program; in addition the opponents of the go day freeze bill had repeatedly employed the acceptance by the Office of Defense Mobilization of planning responsibility as an argument against the Capehart bill. The mandate for preparedness planning, originating in the National Security Act of 1947 , had now been reaffirmed in 1953 .

\section{The ODM Planning Program}

To some extent, the character of the stabilization planning activities of the Office of Defense Mobilization were pre-determined by the Administration's position on the Capehart bills; in part by the precedent of action steps in previous emergencies; in part by the acceptance in 1953 by a large group in Congress of a temporary general freeze as the appropriate point for the beginning of any future program of direct stabilization controls; and in part by subsequent and extensive re-examination of this position on the merits.

\section{A. The Initial Objectives of Planning}

The general approach of ODM stabilization planning is relatively well known; it has been repeated by its Director and various other officials of the agency on public occasions and in appropriations hearings, ${ }^{21}$ and it has appeared in various trade periodicals. ${ }^{22}$ The agency has prepared some drafts of bills which carry out the 90 day freeze objective. These bill are not being offered now by ODM, but are available to the President should the time come when he believes such legislation is necessary. The agency has done much less work in formulating longer-range bills which Committees of the Congress might wish to use in framing the kind of legislation that would supersede a go day freeze. Also the agency has formulated a comprehensive general freeze regulation which could be used to implement a go day freeze bill, or which could be adapted promptly to any stabilization legislation which Congress might enact. On the assumption that any such legislation would permit modifications in a straight price freeze, the planning calls for giving priority to the development of tailored industry regulations for those industries whose pricing practices do not lend themselves well to the individual freeze technique.

Apart from the price area, the ODM approach has been to formulate related policies for controls in the rent, wage, salary, and rationing fields. Although these other areas of stabilization responsibility raise other problems than those of com-

\footnotetext{
${ }^{20}$ Id. at 24-29.

${ }^{21}$ E.g., Hearings before the House Subcommittee on Appropriations, Supplemental Appropriations Bill, 1954, 83d Cong., rst Sess. 299-30r, 304-305 (Part I) (1953); Hearings before the Senate Subcommittee on Appropriations on H. R. 6200, 83d Cong., 1st Sess. 439 (1953); Hearings before the House Subcommittee on Appropriations, Independent Offices Appropriation Bill, 1955, 83 Cong., 2d Sess. I2591265 (Part 2) (1954). 46.

${ }^{22}$ See, for example, Green, Here's Where War Mobilization Stands, Nation's Business, May, 1954, p.
} 
modity pricing, the thread of consistency with the pricing program and of equal treatment (so far as that may be practicable) runs throughout the planning.

\section{B. Emphases of Planning}

In addition to the principle of equal sacrifice under controls, certain other emphases have developed in the course of the program. Some of these grow out of an effort to gain by past operating and planning experiences; some out of an exploration of how to increase the role of indirect economic controls in a mobilization and war economy; others out of a combination of insufficient appropriations and an urgent international situation; and most importantly out of the problem presented by atomic attack.

At the outset, to the extent practicable, the planning program seeks to make more extensive use of the role of so-called "indirect" fiscal and credit measures which are administered by the Treasury Department and the Federal Reserve Board. ${ }^{23}$ Although widely used in the post-Korean period, from many quarters has come the suggestion that they should play an even greater role in any future emergency. The basic argument in favor of their greater utilization is the fact that they deal directly with the source of inflationary pressures-namely, excessive purchasing power. The extent to which they can be effectively utilized in case of atomic attack upon the United States is an unresolved question. Through the work of the Interagency Emergency Stabilization Committee, it is anticipated that progress can be made in gearing such controls to the remainder of the mobilization effort. This Committee is composed not only of ODM, Treasury, and the Federal Reserve Board, but also of representatives from the Departments of Interior, Agriculture, Commerce, and Labor.

Second, an effort is being made in the planning program to relate price stabilization to other stabilization programs. Although Section 402(d) of the Defense Production Act expressly provided for the integration of wage controls with price controls, the steel case demonstrated that in actual administration the degree of such integration left much to be desired. Other mobilization programs will have an important bearing upon the stabilization program as well. For example, the current program of expanding essential productive capacity (i.e., the mobilization base) ${ }^{24}$ by making possible larger output of goods will tend to reduce the inflationary problem.

Third, the stabilization planning effort has given attention to the timing of both indirect and direct controls. The Korean experience has now made the importance of timing quite clear, if that were not true before. In that situation it was the Congress which insisted upon the inclusion of stabilization authority in the Defense Production Act of 1950 , and when this authority was not employed until January 195I the Administration opened itself up to considerable criticism in Congress and

23 "One of the major problems in this program is to determine the proper balance of indirect measures and direct controls to combat inflation in event of an emergency. Efforts will be directed toward the greater use of credit and fiscal measures. ..." Defense Mobizization: Report to the President BY the DiRector of the Office of Defense Mobilization 23 (October I, I953).

${ }^{24}$ Sce Symposium on the Mobilization Base, 13 FED. B. J. I4I (I953). 
throughout the country. By 1952 it became quite clear that the Executive had failed to employ direct controls at the time when they could have made their most significant contribution. This is a mistake which present planning seeks to avoid.

In the fourth place, present planning emphasizes that we must be flexible in preparing for any future crisis, and that there will be differences in the extent to which different kinds of controls may be necessary. Between the end of World War II and the outbreak in Korea, mobilization planning concentrated on the problems of full mobilization. With the outbreak in Korea, when something less rigorous was called for, it became necessary to improvise a stabilization program for partial mobilization.

Nor does the present planning assume that the next mobilization effort will necessarily be either another World War (like World War II) or another Korea. The lesson has been learned that useful planning must be sufficiently flexible to meet either of these situations, various "in-between" situations, and also attacks upon the United States itself. ${ }^{25}$ The lack of experience makes particularly difficult the task of planning stabilization should an atomic attack befall this country, although it appears somewhat obvious that matters of distribution would take on new importance.

In the fifth place, emphasis has been placed on benefiting from the past two experiences of governmental price-fixing. This has been facilitated by the willingness of many industries to cooperate in reviewing and making recommendations for improving upon past regulatory techniques. It should be pointed out that by this time the greatest reservoir of price control expertise is in industry. This willingness of industry groups to cooperate has been fortunate because of severe budgetary restrictions on the Office of Defense Mobilization.

Finally, closely related to the emphasis upon industry service is a related emphasis upon the development of actual operational documents. The tendency of any planning operation is the continuous production of policy memoranda, together with extensive conferences dealing in important but philosophic generalities. This error has been avoided by emphasis upon the development of operational documents in line with the general policy approach. Such an approach has been useful in attracting the industry people who can make an effective contribution to stabilization planning. This emphasis on the operational aspects of stabilization planning also gives promise of reducing the delays which in the past have prevented the adequate and prompt implementation of stabilization programs.

25 "Therefore, in accordance with the promises that we made to Congress and the public, we are developing detailed plans for stabilization controls which can be submitted to Congress whenever it is decided that conditions warrant such a move. The objective of this work is to prepare a series of stabilization policies and actions based on alternative assumptions of the kind of emergencies that may face us in the future. This will include preparation of actions which would be necessary to mect the problems of stepped-up mobilization and full mobilization, with or without direct attack on the United States." Defense Mobilization: Report to the President by the Director of the Ofpice of Defense Mobilization 23 (October I, r953). 


\section{Other Problems of Stabilization}

The foregoing discussion by no means touches upon all the major problems of planning or operating an emergency stabilization program. All of the other articles in this symposium present specific problems which were of the greatest significance during the post-Korean program. ${ }^{26}$ Significantly, the same problems were also of major significance during the World War II program, which has been more extensively recorded for posterity. ${ }^{27}$ An analysis of that experience will show that while the OPA experience and climate differed greatly from that of OPS, by and large the same instrumentalities and techniques of control were employed, although with a different rigor. Particularly when it is realized that the post-Korean stabilization effort began its life with an anti-OPA bias, this eventual reliance upon similar measures is important to price control technicians.

Among the remaining major problems which are not here treated, the farm, labor, and organizational ones are perhaps the most pressing. Just how to gear into a ceilings program the existing farm price support program has been a problem since the passage of the Emergency Price Control Act of 1942. With the Little Steel Formula, the wage problem of World War II was kept in bounds until the 1946 settlement on steel prices and wages helped to push that program to its oblivion. The post-Korean wage program ran into serious trouble in the more famous steel wage case of 1952. Finally, how to establish or even plan for an effective field organization without adequate funds, and knowing full well that the organization may reach tremendous proportions (as during World War II), is alone enough to tax anyone's ingenuity. Yet in terms of an attack upon the United States, this might well be far more important than settling most of the substantive issues.

These are the kinds of issues which the planner of today must strive to solve to meet the possible problems of tomorrow.

${ }^{20}$ In addition, there are a number of unpublished descriptions of the problems arising in specific commodity areas during the post-Korean experience, as well as studies in the wage, salary and rent fields.

${ }^{27}$ The United States Government Printing Office published several volumes on the OPA experience, of which these were the most important: OPA BibLIography, 1940-1947; OPA CHronology; Minutes of the Price administration Committee; The Beginnings of OPA; A History of Ration Banking; Wartime Apparel Price Control; Field Administration of Wartime Rattoning; OPA and the Public Uttlity Commissions; Studies in Industrial Price Control; Problems in Price Control: Pricing Standards; Problems in Price Control: Pricing Techniques; Problems in Price Control: Changing Production Patterns; Problems in Price Control: Stabilization Subsidies; Problems in Price Control: Legal Phases; Problems in Price Control: National Office Organization and Management; Studies in Food Rationing; Volunteers in OPA; and A Short History of OPA. 